\title{
Peningkatan Implementasi Sanitasi Lingkungan melalui Pelatihan bagi Siswa Sekolah Dasar di Bogor
}

\section{(Improved Environmental Sanitation Implementation through Training for Elementary School Students in Bogor)}

\author{
Ima Kusumanti ${ }^{*}$, Hanna Maria Sitindaon ${ }^{2}$, Fiha Nurfatharani ${ }^{2}$, Anisa Istiqomah ${ }^{3}$ \\ 1 Program Studi Teknologi Produksi dan Manajemen Perikanan Budidaya, Sekolah Vokasi Institut Pertanian Bogor, \\ Jl. Kumbang No.14, RT.02/RW.06, Babakan, Kecamatan Bogor Tengah, Bogor, Jawa Barat 16128. \\ ${ }^{2}$ Asisten Dosen Program Studi Teknologi dan Manajemen Lingkungan, Sekolah Vokasi Institut Pertanian Bogor, \\ Jl. Kumbang No.14, RT.02/RW.06, Babakan, Kecamatan Bogor Tengah, Bogor, Jawa Barat 16128. \\ 3 Program Studi Teknik Lingkungan, Institut Teknologi Yogyakarta, Jl. Raya Janti Km.4 Gedongkuning, \\ Kecamatan Banguntapan, Bantul, Daerah Istimewa Yogyakarta 55198. \\ *Penulis Korespondensi: imakusumanti@apps.ipb.ac.id \\ Diterima September 2020/Disetujui Februari 2021
}

\begin{abstract}
ABSTRAK
Perilaku hidup bersih dan sehat (PHBS) di sekolah merupakan kegiatan memberdayakan siswa, guru, dan masyarakat lingkungan sekolah untuk mau melakukan pola hidup sehat dan menciptakan sekolah sehat. Kegiatan bertujuan untuk mensosialisasikan tentang pentingnya sanitasi lingkungan di sekolah dan menumbuhkan kesadaran mengenai pentingnya kesehatan lingkungan di sekolah, melalui sosialisasi dan pelatihan implementasi yang dilaksanakan pada bulan September 2019 di Kecamatan Bantarjati, Kota Bogor Jawa Barat. Kegiatan diikuti oleh siswa kelas 4 (empat) SD sebanyak 35 siswa dengan kegiatan pelaksanaan yang terdiri dari tahap persiapan, inti program dan evaluasi, kemudian dianalisis secara kualitatif melalui pengamatan lapangan dan wawancara pemahaman peserta. Implementasi sanitasi yang telah dilakukan pada siswa merupakan salah satu sanitasi dasar, yaitu mencuci tangan dan memilah sampah berdasarkan jenisnya. Peraturan Menteri Kesehatan Nomor 3 tahun 2014 tentang Sanitasi Total Berbasis Masyarakat (STBM) menjelaskan bahwa cuci tangan pakai sabun adalah perilaku cuci tangan dengan menggunakan air bersih yang mengalir dan sabun. Sampah secara umum dibagi menjadi dua yaitu sampah organik dan anorganik. Kedua sampah ini memiliki manfaat untuk kita, namun juga ada dampaknya untuk lingkungan. Hasil kegiatan menunjukkan bahwa tingkat pemahaman siswa-siswai SDN 6 Bantarjati Bogor memiliki tingkat pemahaman yang cukup baik. Namun demikian, sosialisasi secara berkala perlu dilakukan sebagai proses pembentukan karakter siswa dan menjadi kebiasan yang dilakukan sehingga dapat diterapkan dalam kehidupan sehari-hari melalui pelatihan implementasi (praktik).
\end{abstract}

Kata kuci: kesehatan, lingkungan, sampah, sanitasi

\begin{abstract}
Clean and healthy life behavior (PHBS) in schools is an activity to empower students, teachers, and the community to run a healthy lifestyle and create healthy schools. The activity aims to socialize the importance of environmental sanitation in schools and raise awareness about the importance of environmental health in schools, through socialization and implementation training conducted in September 2020 in Bantarjati District, Bogor City, West Java. The activity was followed by students in grade 4 (four) elementary school totaling 35 students with implementation activities consisting of the preparation, core program and evaluation stages, then analyzed qualitatively through field observations and participant understanding interviews. The implementation of sanitation that has been carried out on students is one of the basic sanitation, which is washing hands and sorting waste by type. Minister of Health Regulation No. 3 of 2014 concerning STBM explains that washing hands with soap is the behavior of washing hands using clean running water and soap. Waste in general is divided into two, namely organic and inorganic waste. Both of these wastes have benefits for us, but they also have an impact on the environment. The results showed that the students' level of understanding at SDN 6 Bantarjati Bogor had a fairly good level. However, periodic socialization needs to be carried out as a process of forming student character and becomes a habit that is carried out so that it can be applied in everyday life through implementation training (practice).
\end{abstract}

Keyword: environmental, garbage, health, sanitation 


\section{PENDAHULUAN}

Kesehatan lingkungan sangat dipengaruhi oleh Perilaku Hidup Bersih dan Sehat (PHBS), yang merupakan perilaku kesehatan yang dilakukan karena kesadaran pribadi sehingga setiap individu mampu menolong diri sendiri pada bidang kesehatan serta memiliki peran aktif dalam aktivitas masyarakat. Perilaku hidup sehat dan bersih pada dasarnya merupakan sebuah upaya menularkan pengalaman mengenai pola hidup sehat memalui individu, kelompok ataupun masyarakat luas dengan jalur-jalur komunikasi sebagai media berbagi informasi. PHBS di sekolah merupakan kegiatan memberdayakan siswa, guru, dan masyarakat lingkungan sekolah untuk mau melakukan pola hidup sehat dan menciptakan sekolah sehat. Manfaat PHBS di sekolah adalah mampu menciptakan lingkungan yang bersih dan sehat.

Sanitasi lingkungan meliputi beberapa kegiatan, mulai dari penyediaan air yang bersih dan aman, pembuangan limbah baik dari manusia, hewan maupun industri, sanitasi makanan, udara bersih dan aman, serta rumah yang bersih dan aman (Novianti \& Pertiwi 2018). Namun demikian, pada penerapannya sanitasi tidak terbatas pada lingkungan rumah saja, tetapi juga meliputi tempat umum seperti perkantoran, tempat ibadah, dan sekolah. Sekolah perlu disertai dan didukung oleh kondisi sanitasi yang sehat, karena sebagai tempat berlangsungnya aktivitas siswa memiliki peran mendidik. Selain itu, sekolah juga bermanfaat sebagai sarana pembentukan sumber daya manusia yang unggul. Pada kenyataannya kebersihan lingkungan sekolah sebagai bagian dari prasarana pendidikan sering dilupakan, sehingga penyebaran penyakit dapat terjadi secara cepat kepada siswa di lingkungan sekolah. Berdasarkan kajian yang dilakukan oleh UNICEF Indonesia, terlihat bahwa angka kematian anak karena diare, salah satunya disebabkan oleh kebersihan lingkungan dan sanitasi yang tidak terjaga. Beberapa kajian yang dilakukan menyatakan bahwa sanitasi yang ada di lingkungan sekolah masih sangat rendah.

Kondisi kesehatan lingkungan tentunya akan berpengaruh pada tingkat kesehatan peserta didik di lingkungan tersebut. Melihat pentingnya kesehatan lingkungan yang merupakan komponen dari sanitasi lingkungan, maka dilakukan kegiatan sosialisasi pentingnya sanitasi pada lingkungan, salah satunya pada SDN 6 Bantarjati Bogor. Tujuan kegiatan implementasi sanitasi lingkungan adalah untuk mensosialisasikan tentang pentingnya sanitasi lingkungan di sekolah dan menumbuhkan kesadaran mengenai pentingnya kesehatan lingkungan di sekolah. Kegiatan ini diharapkan dapat memberikan wawasan kepada siswa sekolah dasar tentang pentingnya menjaga sanitasi lingkungan dan juga melatih siswa untuk dapat menerapkan perilaku hygiene dalam kehidupan sehari-hari.

\section{METODE PELAKSANAAN KEGIATAN}

\section{Lokasi dan partisipan kegiatan}

Kegiatan ini dilaksanakan di Sekolah Dasar Negeri 6 Bantarjati, Jl. Taweuran Raya No.6 Perumnas Bantarjati, Kecamatan Tegalgundil, Kota Bogor Utara, pada Desember 2019. Partisipan pada kegiatan ini adalah siswa-siswi SDN 6 Bantarjati kelas 4 sebanyak 35 siswa

\section{Metode Pelaksanaan Kegiatan}

Adapun metode pelaksanaan kegiatan terdiri dari tahap persiapan, inti kegiatan, dan evaluasi.

\section{- Tahap persiapan}

Tahap persiapan yang dilakukan berupa sosialisasi (pengantar) dan perizinan kepada Kepala Sekolah SDN 6 Bantarjati Bogor, serta persiapan alat dan bahan pendampingan. Adapun beberapa alat dan bahan yang digunakan terdiri dari karton, sisa (sampah) organik dan non organik, kerdus, dan kertas bekas.

\section{- Tahapan inti kegiatan}

Tahap inti kegiatan terdiri dari proses pendampingan kepada siswa/siswi SDN 6 Bantarjati. Pertama, dimulai dengan perkenalan, pengantar (sambutan), membentuk kelompok, dan membuat yel-yel untuk membangun semangat peserta. Selanjutnya, penyampaian materi secara teoritis oleh tim. Penyampaian materi ini bertujuan untuk memberikan pemahaman meliputi memilah sampah organik-anorganik dan demo tahapan mencuci tangan yang benar. Materi yang disampaikan diimplementasikan dengan permainan lomba pengumpulan sampah dan pemilahan sampah, dilanjutkan dengan senam mencuci tangan.

\section{- Evaluasi}

Akhir kegiatan ditutup dengan kuis singkat yang membahas tentang penerapan program selama pelaksanaan kegiatan. Hasil kegiatan yang 
didapatkan, dilanjutkan dengan menggunakan desain penelitian deskriptif yang memberikan gambaran secara mendalam mengenai kondisi sanitasi dan kebersihan Sekolah Dasar. Pengolahan data dilakukan dengan menguraikan data dalam bentuk kalimat teratur, runtun dan efektif sehingga memudahkan pemahaman data.

\section{Metode Pengumpulan Data}

Metode Pengumpulan data dilakukan berdasarkan pengamatan lapangan dan wawancara pemahaman peserta melalui observasi langsung kepada siswa-siswi SDN 6 Bantarjati dan wawancara terhadap kondisi prasarana yang ada. Selanjutnya data yang didapatkan dari hasil observasi, dianalisis secara umum dan disajikan dalam bentuk tabulasi.

\section{HASIL DAN PEMBAHASAN}

\section{Kondisi Umum Sanitasi Sekolah Dasar Bantarjati 6 Bogor}

Berdasarkan observasi yang dilakukan selama kegiatan berlangsung, terdapat beberapa variabel yang diamati dan dikategorikan berdasarkan tingkat kelayakan yang ada dalam lingkungan sekolah, yang disajikan Tabel 1. Berdasarkan hasil pengamatan yang dilakukan di SDN Bantarjati 6 yang tertera pada Tabel 1 menunjukkan bahwa dari lima kriteria yang ada, terlihat bahwa lokasi sekolah kurang layak, yaitu pada lokasi sekolah, bangunan langit-langit sekolah, dan pencahayaan. Lokasi sekolah menjadi hal yang perlu diperhatikan karena lokasi sekolah yang berada tepat di pinggir jalan menjadi perhatian khusus yang perlu menjadi bahan pertimbangan seperti banyaknya ke- bisingan dan juga polusi udara yang cukup tinggi. Selain itu, rawan banjir dan lokasi letak dekat dengan selokan dan saluran air juga harus dapat dikelola dengan baik. Langit-langit sekolah terlihat masih banyak terdapat kotoran diakibatkan pembersihan tidak dilakukan berkala. Selain itu, pencahayaan yang ada dalam ruangan kelas tidak masuk secara maksimal, karena warna kaca yang gelap dan juga beberapa jendela tidak berfungsi dengan baik. Berdasarkan data yang didapatkan dari Profil Sanitasi Sekolah Tahun 2017, Kementrian Pendidikan dan Kebudayaan Pusat Data dan Statistik Pendidikan dan Kebudayaan, bahwa air, sanitasi, dan kebersihan merupakan tiga indikator yang saling berkaitan satu dengan lainnya. Ketersediaan akses pada sanitasi sekolah merupakan prasyarat terciptanya lingkungan sekolah yang aman, bersih, dan sehat. Secara global, sanitasi sekolah merupakan salah satu prioritas pembangunan yang termasuk ke dalam tujuan 4a pada Tujuan Pembangunan Berkelanjutan (TPB) atau Sustainable Development Goals (SDGs).

Pemanfaatan halaman sekolah SDN Bantarjati 6 sudah cukup baik. Halaman sekolah banyak ditanami berbagai jenis tanaman, seperti tanaman perdu yang dapat menyerap polusi udara. Hal ini sangat penting untuk mendukung SDN Bantrajati 6 yang banyak dilintasi oleh kendaraan umum. Halaman yang ada juga dimanfaatkan sebagai taman sekolah, sehingga diharapkan selain memberikan nilai estetika (keindahan), tetapi juga memberikan kenyamanan bagi civitas sekolah. Hal ini sudah sesuai dengan syarat pemanfaatan halaman sekolah dasar oleh Keputusan Menteri Kesehatan Republik Indonesia No. 1429 tahun 2006. Namun demikian, pada hasil obsevasi pada bangunan sekolah menunjukkan

Tabel 1 Kondisi Umum SDN Bantarjati 6

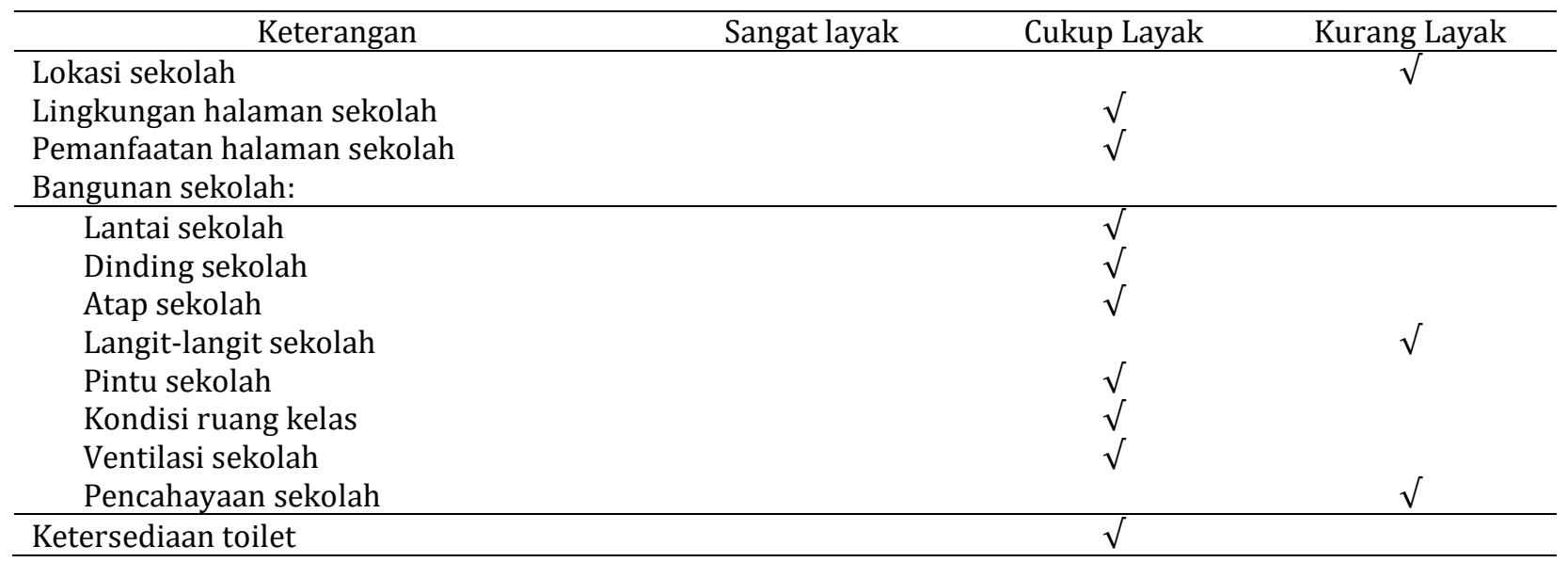


bahwa bangunan SDN Bantarjati 6 masih terdapat beberapa kriteria bangunan yang kurang layak, yaitu pada langit-langit sekolah dan juga ventilasi. Pada langit-langit sekolah masih ditemukan ada yang berlubang yang jika tidak segera diperbaiki dapat menimbulkan penyakit dan tempat bersarangnya tikus, nyamuk, dan serangga lainnya. Berdasarkan aturan Menteri Kesehatan Republik Indonsia Tahun 2006 diketahui bahwa syarat langit-langit sekolah yang memenuhi syarat adalah dengan tinggi dari lantai minimal $2,5 \mathrm{~m}^{2}$.

Ventilasi harus memenuhi persyaratan sebesar 5\% dari luasan lantai. Berdasarkan hasil observasi yang dilakukan, jumlah jendela yang ada sudah cukup banyak, namun dalam perawatannya terlihat masih kurang sehingga banyak ditemukan debu dan juga kaca mati yang tidak dapat dibuka untuk dapat mengalirkan udara. Ventilasi sangat penting terhadap tingkat kenyamanan dan juga kesehatan. Kajian yang dilakukan oleh Razak et al. (2015) menjelaskan bahwa ventilasi sangat penting karena pergerakan udara selain untuk mengganti udara kotor dengan udara bersih, juga merupakan tindakan pengkondisian lingkungan yang sangat berdampak pada kenyamanan termal. Kurangnya ventilasi akan berpengaruh pada kurangnya aliran udara, sehingga tingkat kelembaban yang tinggi dapat menghambat masuknya sinar

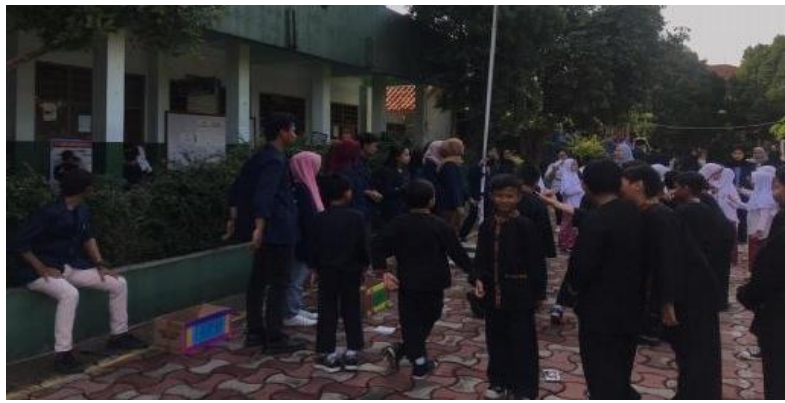

a matahari ke dalam ruangan. Selain itu, bakteri pathogen juga rawan untuk tumbuh dan berkembang pada kelembapan yang tinggi (Trahati 2015).

Selanjutya pada kebersihan dan ketersediaan toilet, SDN Bantarjati 6 sudah cukup baik. Toilet memiliki saluran pembuangan yang lancar, dan memenuhu syarat fisik (air tidak berwarna, berbau, dan berasa) (Kemenkes 2017). Air yang digunakan harus memenuhi kebutuhan siswa dan berasal dari sumber yang aman, artinya bebas dari kontaminasi kuman atau bibit penyakit, bebas dari substansi kimia yang berbahaya (Novianti \& Devi 2018). Menurut Keputusan Menteri Kesehatan Republik Indonesia No. 1429 tahun 2006 persyaratan kesehatan lingkungan, kuantitas air sekolah dasar yang memenuhi syarat adalah mencukupi dengan menggunakan sistem perpipaan atau mencukupi dengan menggunakan sarana selain perpipaan.

\section{Pelaksanaan Kegiatan}

Pelaksanaan penyuluhan dan implementasi sanitasi lingkungan, dilakukan dengan beberapa kegiatan interaktif, dimulai dari pembagian dan penjelasan kelompok (Gambar 1), peserta mempersiapkan games dan membuat yel-yel masingmasing kelompok (Gambar 2), games dan setelahnya (Gambar 3), praktik cuci tangan (Gambar 4), senam sehat hingga tanya jawab seputar

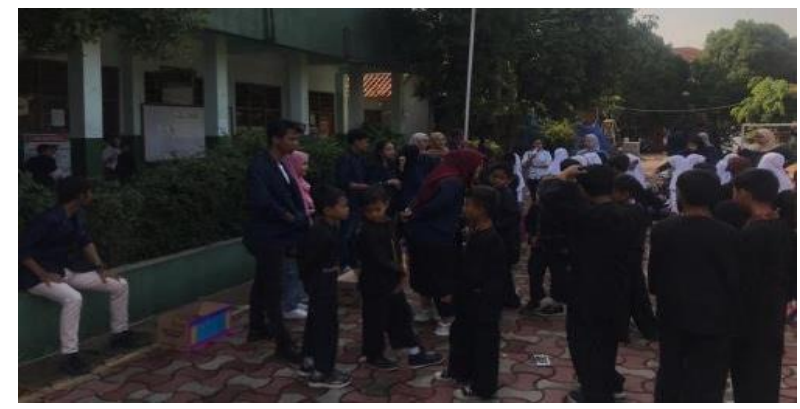

b

Gambar 1 a) Pembagian kelompok dan b) Penjelasan kelompok.
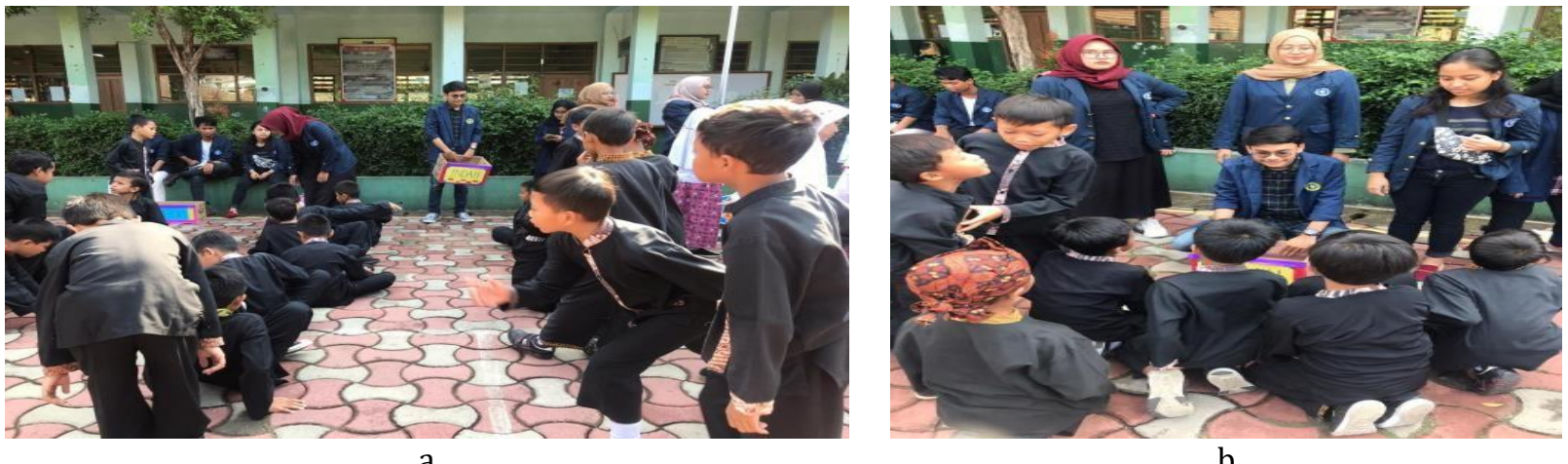

$\mathrm{b}$

Gambar 2 a) Persiapan games dan b) Membuat yel-yel. 


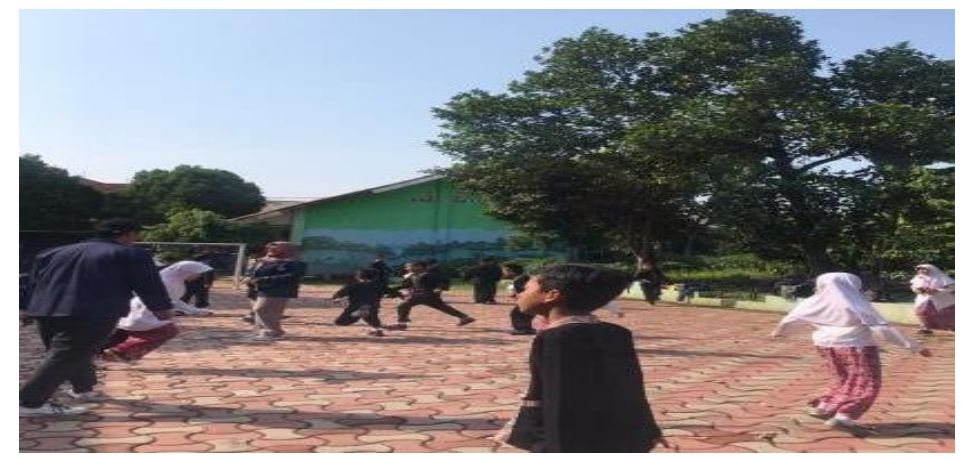

a

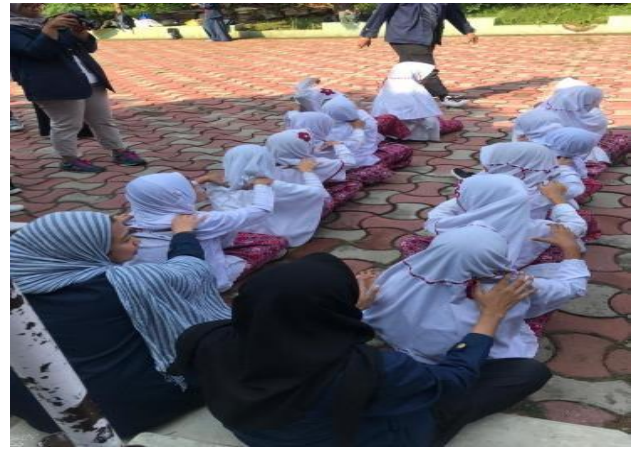

b

Gambar 3 a) Games dan b) Setelah games.

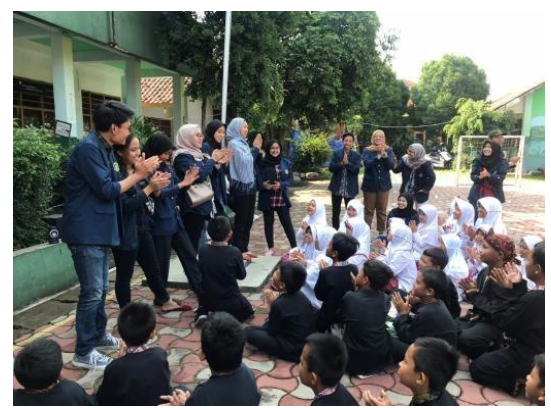

a

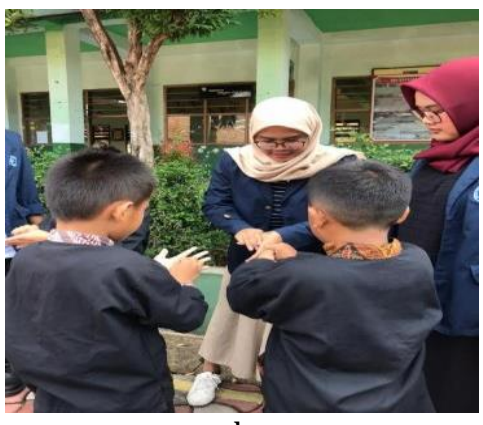

b

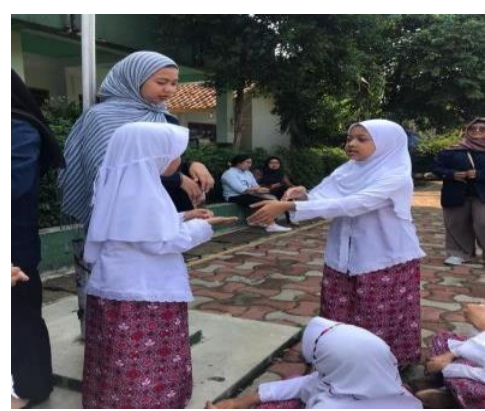

C

Gambar 4 a, b, dan c Praktik cuci tangan.

pamahaman siswa terhadap pentingnya sanitasi dan diakhiri dengan foto bersama.

Kesehatan menjadi bagian yang penting untuk dimiliki oleh setiap orang agar dapat melakukan aktivitas. Kesadaran akan pentingnya kesehatan perlu ditanamkan sejak usia sedini mungkin pada anak usia sekolah. Upaya yang dilakukan oleh pemerintah, yaitu melalui program promosi kesehatan sekolah atau Health Promoting School (Depkes RI 2006). Lingkungan sekolah yang sehat akan mendukung tumbuh kembang perilaku hidup sehat serta berdampak bagi kesehatan jasmani maupun rohani. Kegiatan belajar mengajar juga akan terganggu jika lingkungan sekolah tidak sehat. Kesehatan lingkungan sekolah bertujuan untuk meningkatkan, mewujudkan derajat kesehatan, dan pengembangan siswa secara optimal.

Andriani (2013) menjelaskan bahwa untuk membiasakan hidup sehat di lingkungan sekolah mencakup beberapa hal, yaitu penyediaan air bersih yang memenuhu syarat biologis agar terhindar dari bibit penyakit, parasit, dan bahan kimia (Chandra 2006), harus ada tempat pembuangan sampah (Aisa 2018) dan pengelolaannya serta tersedianya pembuangan kotoran manusia atau WC di lingkungan sekolah yang memadai, sumur resapan (Wibowo 2013) dan ini semua merupakan fasilitas sanitasi lingkungan khususnya lingkungan sekolah. Masalah kese- hatan yang sering timbul pada anak usia sekolah, yaitu gangguan perilaku, penyakit infeksi, penyakit saluran pencernaan, penyakit saluran pernafasan, penyakit kulit, dan malnutrisi (Amin 2017). Masalah-masalah tersebut karena kurangnya pengetahuan serta kesadaran akan pentingnya kesehatan terutama kebiasaan mencuci tangan dan mengkonsumsi jajanan sehat. Cuci tangan merupakan salah satu solusi yang mudah dan efektif dalam pencegahan penyakit menular dan jajanan yang sehat juga dapat mencegah gangguan saluran pencernaan (Depkes RI 2006).

Sanitasi sekolah sangat berkaitan erat dengan penyakit, sehingga jika lingkungan sekolah memiliki sanitasi yang kurang baik, dapat berpotensi menimbulkan penularan penyakit, khususnya peserta didik. Beberapa penyakit berbasis lingkungan karena sanitasi buruk tersebut diantaranya diare, ISPA, dan cacingan. Chadijah (2014) memaparkan bahwa cacingan merupakan penyakit yang paling mudah terjadi dan mendominasi pada lingkungan sekolah. Selain itu, berdasarkan data UNICEF Indonesia dalam ringkasan kajian air bersih, sanitasi, dan kebersihan menyebutkan bahwa angka kematian anak berusia di bawah lima tahun akibat diare yang berasal dari sumber air minum yang tercemar dan juga kurangnya perhatian pada lingkungan sekitar. Penyakit tersebut tentunya 
dapat diminimalisir dengan menerapkan kebiasaan menjada kebersihan, salah satunya mencuci tangan dengan air mengalir dengan menggunakan sabun. Perilaku mencuci tangan secara tepat dapat mengurangi resiko penyakit diare sebesar $42-47 \%$. Sanitasi lingkungan yang kurang memenuhi persyaratan kesehatan, personal hygiene yang buruk, serta air yang terkontaminasi selain berpotensi menyebabkan diare, juga dapat menyebabkan penyakit lain seperti disentri, kolera, tipus, hepatitis, leptospirosis, malaria, demam berdarah, kudis, penyakit pernapasan kronis, dan infeksi parasit usus (Feryasari 2015).

Implementasi sanitasi yang telah dilakukan pada anak-anak kelas 4 SDN Bantarjati 6 Bogor merupakan salah satu sanitasi dasar, yaitu mencuci tangan dan memilah sampah berdasarkan jenisnya. Cuci tangan adalah salah satu komponen sanitasi dasar. Cuci tangan yang baik akan menghilangkan kuman yang menempel di tangan sehingga dapat mencegah penyakit karena tangan merupakan bagian tubuh yang paling cepat menularkan penyakit. Hand cleansing adalah suatu kegiatan yang secara fisik bertujuan untuk menghilangkan kotoran, material organik atau mikroorganisme (Santi \& Azmi 2018). Hal ini didukung oleh kajian yang dilakukan oleh Dewi (2011) yang menyebutkan bahwa penyediaan air bersih, sanitasi dan kebersihan toilet, sarana pembuangan air limbah merupakan beberapa indikator dalam fasilitas sanitasi sekolah yang perlu diperhatikan.

Berdasarkan Peraturan Menteri Kesehatan Nomor 3 tahun 2014 tentang STBM menjelaskan bahwa cuci tangan pakai sabun adalah perilaku cuci tangan dengan menggunakan air bersih yang mengalir dan sabun. Metode yang digunakan untuk mengajarkan langkah-langkah cuci tangan yang baik dan benar berupa gerakan senam dengan musik. Anak-anak dikumpulkan di lapangan dan berbaris rapi kemudian mengikuti instruksi dari penanggung jawab senam. Senam cuci tangan dilakukan selama 5 menit yang diikuti juga oleh beberapa guru. Setelah senam berakhir, anak-anak diberikan sosialisasi mengenai jenis-jenis sampah organik dan anorganik. Selanjutnya diadakan games untuk mengetahui sejauh mana pemahaman anak-anak tentang sampah organik dan anorganik. Games dilakukan dengan pembagian kelompok kecil terlebih dahulu, kemudian setiap kelompok secara bergantian menyebutkan perbedaan sampah organik dan anorganik.
Sampah secara umum di bagi menjadi dua, yaitu sampah organik dan anorganik. Kedua sampah ini memiliki manfaat untuk kita, namun juga ada dampaknya untuk lingkungan. Sampah organik adalah limbah yang bersal dari sisa makhluk hidup (alam) seperti hewan, manusia, tumbuhan yang mengalami pembusukan atau pelapukan. Sampah ini tergolong sampah yang ramah lingkungan karena dapat diurai oleh bakteri secara lami dan berlangsungnya cepat. Sampah anorganik adalah sampah yang berasal dari sisa manusia yang sulit untuk diurai oleh bakteri, sehingga membutuhkan waktu yang cukup lama (hinga ratusan tahun) untuk dapat di uraikan (Taufiq \&Fajar 2015).

\section{Pelaksanaan Kegiatan}

Kegiatan terlaksana sesuai tujuan yang telah ditentukan. Peserta mengikuti kegiatan dengan semangat dan gembira. Penyuluhan yang diberikan dapat dimengerti oleh siswa/siswi sekolah dasar dan mudah untuk diimplementasikan pada kehidupan sehari-hari. Peserta berkumpul ditengah lapangan untuk perkenalan dan pengantar (sambutan). Peserta membentuk beberapa kelompok dan setiap kelompok diminta membuat yel-yel untuk membangun semangat serta kekompakan. Selanjutnya, penyampaian materi kegiatan. Penyampaian materi ini bertujuan untuk memberikan pemahaman teoritis meliputi memilah sampah dan mencuci tangan. Materi kemudian diimplementasikan dengan permainan lomba pengumpulan sampah dan pemilahan sampah, dilanjutkan dengan senam mencuci tangan yang baik dan benar

Games yang dilakukan berupa perlombaan beregu di mana terdapat 5 regu, satu regu beranggotakan 8 anak. Dua regu bertugas untuk mengumpulkan sampah organik, sedangkan tiga lainnya bertugas untuk mengumpulkan sampah anorganik. Setiap regu dipandu oleh satu penanggung jawab. Cara bermain games tersebut, yaitu mengumpulkan sampah yang sudah disebar di lapangan sesuai dengan ketentuan setiap regu. Sampah yang sudah terkumpul kemudian dihitung jumlahnya untuk ditentukan pemenangnya. Setelah bermain games mengumpulkan sampah, anak-anak menerapkan cara mencuci tangan yang baik dan benar agar terbebas dari kuman dan penyakit. Sesi selanjutnya adalah pembagian hadiah bagi pemenang dan foto bersama dengan guru dan kepala sekolah. Acara ditutup dengan pembagian hadiah dan dokumentasi. 


\section{Pelatihan Lingkungan}

Implementasi Kebersihan

Pelatihan yang diberikan merupakan implementasi sanitasi dasar. Siswa dilatih untuk mencuci tangan dan memilah sampah sesuai jenisnya. Pelatihan dengan cara senam cuci tangan dilakukan selama 5 menit yang diikuti pula oleh beberapa guru. Pelatihan memilah sampah dilakukan dengan cara sosialisasi mengenai jenis-jenis sampah organik dan anorganik kepada siswa. Selanjutnya diimplementasikan melalui permainan untuk mengetahui sejauh mana pemahaman siswa mengenai sampah organik dan anorganik.

Kegiatan yang dilaksanakan memiliki kelebihan untuk memberikan wawasan dan pengetahuan kepada siswa tentang teori sanitasi dasar, serta siswa dengan mudah memahami dan semangat untuk menerapkan di kehidupan sehari-hari. Untuk menyempurnakan berlangsungnya kegiatan, dibutuhkan fasilitas sarana prasana yang lebih memadahi. Kegiatan tersebut juga memberikan hal positif untuk kesehatan siswa dan kesehatan lingkungan sekolah.

\section{SIMPULAN}

Kegiatan penyuluhan dan implementasi yang dilakukan di SDN 6 Bantarjati Bogor menunjukkan bahwa tingkat pemahaman terhadap kebersihan sudah cukup baik, namun demikian perlu dilakukan secara berkala untuk mensosialisasikan tentang pentingnya sanitasi lingkungan di sekolah dan menumbuhkan kesadaran mengenai pentingnya kesehatan lingkungan di sekolah dilakukan dengan sosialisasi cara mencuci tangan yang baik dengan media senam dan sosialisasi mengenai perbedaan sampah organik dan anorganik. Sosialisasi mengenai perbedaan sampah organik dan anorganik disertai dengan permainan lomba pengumpulan sampah dan pemilahan sampah menarik, dan pembuatan yel-yel agar para siswa lebih mudah memahaminya.

Adapun saran yang dapat disampaikan setelah kegiatan penyuluhan dan implementasi ini antara lain: a) Perlu adanya pengecekan secara berkala terhadap pelaksanaan penyuluhan dan implementasi yang dilakukan di SDN 6 Bantarjati Bogor dan b) Perlu kesadaran yang tinggi dari pihak sekolah misalnya melakukan kegiatan kerja bakti secara rutin, sehingga pembersihan lingkungan, maka akan terjaga untuk mewujudkan kebersihan lingkungan yang nyaman.

\section{UCAPAN TERIMA KASIH}

Penulis mengucapkan terima kasih kepada kepala SD Negeri 6 Bantarjati, para guru yang telah berpartisipasi, serta peserta didik yang telah mengikuti penyuluhan dan implementasi sanitasi lingkungan. Selain itu mahasiswa jurusan Teknik dan Manajemen Lingkungan Sekolah Vokasi IPB yang telah berkerjasama untuk melakukan penyuluhan dan implementasi sanitasi lingkungan sebagai bentuk aplikasi dari praktikum Sanitasi dan Toksikologi Lingkungan, sehingga kegiatan dapat berjalan dengan baik dan lancar.

\section{DAFTAR PUSTAKA}

Aisa L, Rakhman SA, Ashmamillah D, Fani DM, Pradana GA. 2018. "Enviro School" Rumah Edukasi Pemanfaatan Sampah dalam Rangka Mewujudkan Generasi Peduli Lingkungan. Agrokreatif Jurnal Ilmiah Pengabdian Kepada Masyarakat. 4(1): 1-11. https://doi.org/ 10.29244/agrokreatif.4.1.1-11

Amin ARZ. 2017. Studi Penghawaan Alami Pada Bangunan Sekolah Dasar di Pinggiran Sungai Musi Palembang. Jurnal Arsitektur Arsir. 1(2): 86-99.

Andriani D. 2013. Studi tentang Sanitasi Lingkungan SD Negeri di Kecamatan Sungai Beremas Kabupaten Pasaman Barat. Sumatera Barat (ID): STKIP PGRI.

Chadijah S, Sumolang, PPF, Veridiana NY. 2014. Hubungan Pengetahuan, Perilaku dan Sanitasi Lingkungan Dengan Angka Kecacingan Pada Anak Sekolah Di Kota Palu. Media Penelitian dan Pengembangan Kesehatan. 24(1): 50-56. https://doi.org/10.22435/mpk.v24i1.3487.5 $0-56$

Chandra B. 2006. Pengantar Kesehatan Lingkungan. Jakarta (ID): EGC.

[Depkes] Departemen Kesehatan RI. 2000. Buku Pedoman Pembinaan Program PHBS diTatanan Pendidikan. Jakarta (ID): Departemen Kesehatan RI.

[Depkes] Departemen Kesehatan RI. 2006. Nomor 1429/MENKES/SK/XII/2006 tentang Pedoman Penyelenggaraan Kesehatan Lingkungan Sekolah. Jakarta: Departemen Kesehatan RI. 
Dewi. (2011). Mari Peduli Sanitasi Sekolah. [Internet]. [Diakses pada:] http://sanitasi.bersih.blogspot.co.id/2016 /06/mari-peduli-sanitasi-sekolah.html.

Feryasari I. 2015. Pemeliharaan Sanitasi Di Sekolah Dasa Negeri Se-Kecamatan Jetis Kabupaten Bantul.[Skripsi]. Yogyakarta (ID): Universitas Negeri Yogyakarta.

[Kemenkes] Kementerian Kesehatan. 2017. Peraturan Menteri Kesehatan Republik Indonesia Nomor 32 tahun 2017 tentang Standar Baku Mutu Kesehatan Lingkungan dan Persyaratan Kesehatan Air untuk Keperluan Higiene Sanitasi, Kolam Renang, Solus per Aqua, dan Pemandian Umum. Jakarta (ID): Kementerian Kesehatan Republik Indonesia.

Kementrian Pendidikan dan Kebudayaan. 2017. Profil Sanitasi Sekolah, Pusat Data dan Statistik Pendidikan dan Kebudayaan. Jakarta (ID).

Novianti D, Pertiwi WE. 2019. Implementasi Sanitasi Lingkungan di Sekolah Dasar: Laporan Inspeksi 2018 Dari Kecamatan Keamatwatu, Kabupaten Serang, Provinsi Banten. Jurnal Kesehatan Lingkungan. 11(3): 175-186. https://doi.org/10.20473/jkl. v11i3.2019.175-188
Peraturan Menteri Kesehatan No 3 Tahun 2014 tentang Sanitasi Total Berbasis Masyarakat.

Razak H, Dedes NG, Jimmy SJ. 2015. Pengaruh Karakteristik Ventilasi dan Lingkungan Terhadap Tingkat Kenyamanan Termal Ruang Kelas SMPN di Jakarta Selatan. AGORA Jurnal Arsitektur. 13(2): 37-69. https://doi.org/ 10.25105/agora.v15i2.2024

Santi AUP, Azmi AB. 2018. Kondisi sanitasi di tiga sekolah dasar negeri di daerah Tangerang Selatan. Holistika Jurnal Ilmiah PGSD. 2(1): 30-36.

Taufiq A, Maulana MF. 2015. Sosialisasi Sampah Organik dan Non Organik serta Pelatihan Kreasi Sampah. Jurnal Inovasi dan Kewirausahaa. 4(1): 68-73.

Trahati M. 2015. Implementasi Pendidikan Karakter Peduli Lingkungan Di Sekolah Dasar Negeri Tritih Wetan 05 Jeruklegi Cilacap. [Skripsi]. Yogyakarta (ID): Universitas Negeri Yogyakarta.

Wibowo A, Al-Rasyid PH. 2013. Penyuluhan Sumur Resapan dan Sanitasi Untuk Edukasi Lingkungan Sehat Sesuai Standar Kesehatan Pada Masyarakat. Jurnal Inovasi dan Kewirausahaan. 2(1). 58-62. 